\title{
Worship in Islam and Contemplation in God's Creation (An Analytical Study)
}

* Dr. Samina Begum, Assistant Professor

** Dr. Hafiz Muhammad Ibrar Ullah, Assistant Professor (Corresponding Author)

*** Dr. Hashmat Begum, Assistant Professor

\begin{abstract}

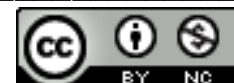

The contemplation of God's creation is one of the greatest forms of worship in Islam every human being, when he observes the different scenes of this universe of colors and smells, enjoys seeing some of them so much that he longs to repeat this pleasure- It is not amazing, therefore, that countless Quranic verses give confidence this action and do so using a range of methods to appeal to every temperament and religious state. The mean is to switch people away from their dulled senses, awful habits, and monotonous familiarity, and encourage them to observe the signs of their Lord in the world with insight and vulnerable hearts. True Islamic contemplation can only spring from a mind that believes in God and a mind that submits to Him and His glorious Attributes. This is the unwavering faith of oneness (tawhÏd), which is to bear witness that the Almighty is the One and only God Who created, governs, and maintain the universe. Any other form of contemplation of the attractiveness and brilliance of the heavens and the earth would be measured atheism or polytheism (shirk) because the contemplator would not be distinguished, let alone admiring and express thanks to the Creator. In all religions, after beliefs, the highest importance is given to worship. Worship and contemplation are inseparable.
\end{abstract}

Keywords: Worship, Contemplation, God's Creation, Attributes

\section{Introduction}

Worship is the name of every action in which a person intends to please Allah and follow the way of the Messenger of Allah, as if these two things, ie meditation and contemplation, and obedience are born in it, then it is pure worship. In the same way, the literal meaning of worship is to humble oneself for the sake of reverence and this is only for Allah. Sometimes worship is also used in the sense of obedience and submission. (Mahnama,2018 ). There are several meanings of the term: adopting the last degree of humility for Allah, working against one's self for the sake of honoring the Lord, and an act which only honors Allah, every Doing what pleases Allah. (Ghazali, 1998). The word worship has three meanings: (1) worship, (2) slavery, (3) obedience, being the only Lord of God, it is necessary for man to be grateful to Him, to ask for prayers from Him, and to worship Him. Bow down to love, this is the first meaning of worship. Man is becoming a slave of God, he should not adopt an independent attitude towards it and should not accept the slavery of anyone else. This is another meaning of worship. A man should obey God's command and follow His law. This is the third meaning of worship. (Maududi , 2007).

That is, they are not blinded by the Qur'anic facts and teachings in worship; Rather, they focus on it with intellect and understanding, and become absorbed in obeying the commands. They listen to the Quranic verses with open ears and see the lessons with their own eyes.

Tact is usually achieved by repeating the verse over and over and trying to understand the meaning - Consciousness can only happen when one knows the meanings and connotations of words, then the result of contemplation is fear, influence, and fear.Jamal, 2008). Concerning the freedom of contemplation, the Qur'an calls for meditation on the natural creations of God in which the human hand plays no part, such as the heavens, the mountains, and the seas. The Qur'an also draws the believers' attention to the bounties with which people have been favored, such as the inventions which God has enabled some to achieve to serve humanity :

Behold! The creation of the heavens and the earth, and the alternation of night and day, and the ark, which sails in the sea for the good of mankind, and that which Allah sanded down water from

\footnotetext{
* Shaheed Benazir Bhutto Women University Peshawar Email: saminaphd@ hotmail.com

** The University of Azad Jammu \& Kashmir Muzaffarabad Email: hafizibrar87@gmail.com

*** Shaheed Benazir Bhutto Women University Peshawar Email: hashmat.begum@sbbwu.edu.pk
} 
the sky, The rotation of the heavens and the clouds that bound between the heavens and the earth are signs for men of understanding. (2:164)

There is a deep connection between worship and contemplation. If one reads in prayer that Allah is the greatest, then if one thinks about it, one is ready to believe that Allah is the greatest. Contemplation is an Arabic word that means to think, reflect and ponder. Contemplation is a mental process in which a person travels to the depths of a single thought, point, or observation by shaking off all his superstitions and thoughts and focusing on them. In all the inspired books and the Qur'an especially meditation or contemplation has been given great importance. Along with worship, there is a great philosophy of contemplation in God's creation (Ghazali, 1998). Man needs divine revelation regarding the correct ways of worship. He cannot determine for himself with his intellect and senses which are the rituals and deeds that can be the source of nearness to God and purification of the soul. His power of thought can only accompany him to a certain extent, and the purification of the soul and the nearness of God are matters beyond that limit. - (Fergusson, ,2008). While many Qur'anic verses encourage meditation on the heavens and the earth in general, and where the human being is considered the most important creation, many verses are specifically concerned with contemplating the creation of humankind. As previously mentioned, the Qur'an uses every means to arouse human hearts from their dulled senses and monotonous familiarity, to witness the signs of the Lord in the heavens and on the earth with alertness and enlightened insight. The verses concerning humankind follow similar methods of encouragement to suit every heart and every emotional state. ( Malik, 2018).

The following verses are examples detailing the creation of man and the favors that God bestowed on those with soft hearts:

And certainly We created man a quintessence [of clay]; then We made him a drop of water in a strong abode.

Then We caused a drop of water to gush forth with blood, then a drop of blood, then a piece of flesh, then bones ،

Then We developed from it another creature. So blessed be God, the best Creator! (23:12-14)

Say: "Look at [and contemplate] what is in the heavens and the earth." But neither Signs nor Warners profit those who do not believe. (10:101)

And how many a sign in the heavens and the earth that people pass by and are unaware of, and most of them do not believe in Allah except in associating others with Allah in His Divinity. (12:105)

What is the matter with you that you do not hope to be honored by Allah, though He has created you in various ways Do you not see how Allah made the seven heavens one above the other and made the moon a light in them and the sun a lamp? (71:13-16)

He Who has made the best of narrations, and created man from dust, then made his progeny from an insignificant sum of water, then healed him, and breathed into him of His spirit, and gave you ears and eyes and hearts? You believe a little truth-(32:7.9)

This planet is gorgeous, inexhaustibly stunning. The man may snatch and take pleasure in this prettiness as much as he desires, and as much as the inventor of this world wishes. The component of beauty in this world is intentional. Faultlessness of creation consequences in realizing beauty. The perfection of creation is evident in the attractiveness of each organ and every creature. Seem to be at the bee, the star, the flower, the morning, the night, the clouds, the shades, this music pervading the whole universe, this perfect and entire harmony. It is an enjoyable expedition in this world of attractiveness and perfection The Qur'an draws our attention to all this, so we may ponder and enjoy it. Hence: "He Who has made everything which He has created most good," is a verse that arouses the heart to trace the aspects of beauty and perfection in this great universe. (Qutb,1979). Contemplation of the creation of the heavens and the earth and all that is included in them is a practice that cannot be impeded by changes in time, place, or the nature of things. It is a free, unrestrained form of worship. It is also a cognitive and emotional process that enlivens the heart and enlightens perception as the mind ascends from contemplating the signs of God in the universe to their Creator and Lord. This is the real meaning of contemplation. ( Malik, 2018 ). Hazrat Abu Thalaba used to worship a lot, it was his custom to go out of the house during the day and night and meditate for a long time on the creation of Allah Almighty: the sky, the stars, etc., then return and prostrate before Allah Almighty. He also died in a state of prostration. (ALAsqalani , 2018 ) 
HazratAunibn Abdullah narrates that I learned from Umm al-Darda 'which worship Hazrat Abu al-Darda used to pay more attention to? she replied: "Contemplation and trust" in contemplating and meditating on the creation of Allah Almighty and taking stock of oneself. Similarly, HazratAbulDarda says, "It is better to meditate on the creation of Allah for one hour than to perform Tahajjud prayers all night long. (Muhammad, 1997). HazratAbulDarda had so much pain in one eye that the light of that eye went out. He was asked: Why did you not pray to Allah Almighty for his healing? He replied: O servant of Allah, I do not have time to pray for forgiveness so that I can pray for the healing of my eye. (Al-Dhahabi ، 1990).

The Prophet said, "A man is the like of his companion, so be careful whom you befriend." The influence of a good example and companionship needs no elaboration. Religion has explained it, observations by average people have affirmed it, and modern experimental social psychology has confirmed it, to the extent that it has become a foregone conclusion. In the same way, that bad example is a great handicap, good example and companionship make one of the most important factors affecting the profundity of the believer's contemplation. It is for this reason that a disciple or murÏd can benefit much from his association and identification with a worshipper who has reached the level of the tranquil soul (al-nafsal-mu ma' innah) in the person of his spiritual master (shaykh). Indeed, the spiritual influence of the companionship of a sage can dramatically change the worldview of his disciple and increase his Islamic meditative ability - (Sean ,2009). Worshiping and meditating in the universe is the virtue of the saints who know Allah Almighty. When these saints meditate on these things, they know for sure that Allah Almighty did not create these things in vain. Upon attaining this certain knowledge, they say: "Our Lord! You have not created all this in vain. Glory be to You above all that is not worthy of Your glory. Created together and for a specific purpose, and all its components are also perfect. "So save us from the torment of Hell, in such a way as to save us from sins, grant us the ability to do good deeds so that we may escape the fire of Hell. And that is the peculiarity of Islam in this regard is that, like the various branches of religion, it has presented a comprehensive, clear, and disciplined guide to the concept of worship and its methods, which is unique in every respect. -( Al Saadi, 1995),

Abu Hurayrah (may Allah be pleased with him) had divided the night into three parts, sleeping in one part, worshiping in the other part, and memorizing the hadiths of the Prophet in the third part. You used to make it a habit of your family to wake them up for worship at night. The wife and her servant had divided the night into three parts, they would spend one-third of the night, then they would wake up their wife, they would also spend one-third of the night in worship, then they would wake the servant for worship. . (Al-Dhahabi, 1990) The servant should be pleased with the Almighty in every situation, whatever the situation may be, and whatever the truth may issue to them, they should not be displeased with anything, and whatever the Almighty bestows on them, whatever it may be. Do not despise it because the Almighty knows their spices better than them, so whatever they do will be better.- ( Al Saadi, 1995) In the Qur'an, it has been made clear in different ways and on different occasions that the universe, the earth, and the heavens and everything in it are created by Allah, the Lord of the worlds, and He alone is the Lord of all and worthy of worship. And whatever happens is determined by Allah, the Creator of the universe, and it all comes into being according to His knowledge and intention, no matter how small or big, it does not happen automatically. And in the Qur'an, it is further stated that Allah has not created this for no reason, but there is a purpose behind it. And man was commanded to understand this purpose and to oblige himself to act according to it, and for this purpose, a man was given special respons ibility for other creatures, that he should spend his life on this earth as his Creator. And to live according to the will of Allah Almighty as well as to act as the administrator on this earth as the vicegerent of his Creator and Master, and in the course of this work to live according to his purpose Knowledge required, resources provided. ( Jan, 2005). He needed two kinds of information, one that he needed to live a life that man could get from his reflection and research and experience, the acquisition of this information is left to man's effort, and his ability to attain and the ability to understand accordingly is the second type of worship in which man humbles himself before his Lord. Man has been told in the books sent down by Allah and through the messengers and angels appointed by Allah, in which the purpose of man's creation and understanding the greatness and benevolence of the Creator and according to it The method of giving thanks is explained, and it is made clear that the best blessings will be bestowed upon those who obey the will and command of its Creator-(Al-Dhahabi, 1990). 
The whole world is for man, and man is for worship; Therefore, just as the left reason is for the horse and the grass is for the horse, so the grass is for the horse. The same left reason that man is for worship and the whole world is for man, consider the whole world for worship. The purpose is to worship the real creation of the world, which is the need of mankind, not its own need. (Nanotvi, 2001).

It is very important to get Islamic teachings only from Islamic sources. The biggest and most basic source of these is the Qur'an and Sunnah. While Is lam has endowed intellect and contemplation with a very high position, this position and number I see very clearly, so in the Holy Qur'an, there are repeated words that emphasize the importance of reason and thought. For example. For a people, do you not understand, do you not meditate, do you not listen? Don't you see-While reciting the verses of the last Ruku of Surah Al-Imran, one should look at the sky, especially it's opening verses in which Allah Almighty has given signs for the wise in the creation of the heavens and the earth and the change of night and day. They say this while meditating in heaven and earth. That is, our Lord! You did not create all this in vain. So save us from the torment of Hell. (Muhammad, 1997).

\section{Conclusion}

Since the creation of the universe, the sun has been the source of light, weight, and heat, and it has been performing its duty without any difficulty. The moon determines the months and years by its radiance and its speed. Standing on their duty, the trees are standing in their place and worshiping God, and benefiting the people with their shade and fruit, Only man is told to worship and meditate, to think, that all these things are made for the benefit of man and all creatures are made to worship this one Lord. All those creatures who have no heart, no intellect, are always engaged in obedience and worship of Allah Almighty, they have no disobedience, no rebellion, the only man has been given the authority to do whatever he wants, but GOD has endowed man with the ability to think and reason. The Lord of the Universe has invited the man to reflect on the beauty of the universe and commands the worship of this one God, especially when the stars shine in it like beautiful lamps. It just not for safety and benefit, but to make every spectator feel the delightful pleasure derived from its beauty by seeing it, and by feeling that its creation, the towers. And guide the lamps to the knowledge of their Maker and the contemplation of His essence. Through this tactic, man should recognize the greatness of his master and use the blessings bestowed by him with the beauty of his personality.

\section{References}

AL Asqalani , I,A,(2018).al isabahfetamez is sahabah, (vol,04). Dar al-kutub al-Ilmiyyah, Beirut.

Al Quran 2:164

Al Quran 32:7.9

Al Quran 71:13-16

Al Quran . 10:101

Al Quran 12:105

Al Quran 23:12-14

Al saadi ,A,N (1995),TafseerSaadi ,( vol 09) Jawziyyah Press

Al-Dhahabi ‘S,M,I (1990). Siyara 'lam al-nubala' (vol.08 )Mu'assasat al-Risalah,bayrut

Fergusson, D,(2008). The Theology of Worship, A Reformed Perspective., Hymns Ancient and Modern Ltd

Ghazali, M, (1998). A Journey Through the Qur'an Themes and Messages of the Holy Qur'an, Dar Al-Takva

Jamal, A, N,( 2008). The most comprehensive worship of Islam, Muradabad, India.

Jan, A, (2005) ,Religion and Cultural Memory,(vol,03). Stanford University Press

Mahnama,W,D,(2018) Monthly NadaiDarulUloomWaqfDeoband, Deoband India.

Malik, B, (2018). contemplation An Islamic PsychospiritualStudy,Viki press, London

Maududi,S,A,A,(2007). Tafheem Al-Quran,(vol. 3) Central Islamic School.

Muhammad ,B,S, (1997). Tabqaat Ibnne Saad,(vol.07) Inab press, labnan

Nanotvi, M, Q, (2001). Discussion Shah Jahanpur,hujjatul Islam, DarulUloom, Deoband

Qutb, S,(1979). Fi zel ul quran, (vol.5)MWH publisher , london.

Sean, F, J, (2009). The History of Yaman, Cambridge University Press 